\title{
'Cisco' Persian Walnut
}

\section{Gale H. McGranahan, David E. Ramos, Harold I. Forde, and Ronald G. Snyder}

\section{U.S. Department of Agrculture, Agricultural Research Service, Department of Pomology, University of California, Davis, CA 95616}

Additional index words. English walnut, Juglans regia, pollenizers, walnut breeding

'Cisco', formerly UC66-178, is released as a potential pollenizer for Persian walnut (Juglans regia L.) cultivars Chandler and Howard. The commonly recommended pollenizer for these cultivars, 'Franquette', lacks precocity and is a relatively large tree. These drawbacks make 'Franquette' undesirable for use as a pollenizer in close plantings. 'Cisco' is both late-leafing and laterally fruitful, with a pollen-shedding period that closely corresponds to stigma receptivity of 'Chandler' and 'Howard'. Lateral fruitfulness is often associated with smaller tree size and precocity.

\section{Origin}

'Cisco' was produced from a controlled pollination made by Harold Forde in 1965 between the Persian walnut cultivars Meylan and Pedro. The male parent 'Pedro' was released in 1968 and resulted from a controlled pollination between 'Payne' and 'Conway Mayette' (Serr and Forde, 1968). Both 'Meylan' and 'Conway Mayette' are lateleafing, terminal-bearing cultivars similar to 'Franquette'. 'Payne' is an early leafing cultivar with lateral bud fruitfulness. 'Cisco' is a half-sib of 'Chandler' and 'Howard' through the common parent 'Pedro'.

\section{Description}

Evaluation of 'Cisco' began when it was a seedling in its fifth leaf in 1970. Three years later, because of its promising attributes, it was grafted onto two northern California black walnut [J. hindsii (Jeps.) Jeps.] and two Paradox walnut (J. hindsii x $J$. regia) rootstocks in the Univ. of California, Davis, selection block. Evaluation of the grafted trees began in their third leaf (1975) and has been continued until now. Traits under evaluation and the method of evaluation have been described (Forde, 1975).

The mean score and range for each trait, compiled for 10 years (1976-85), are presented in Table 1. Data on 'Scharsch Franquette' have been included for comparison. It should be noted, however, that the 'Scharsch Franquette' trees were grafted 5 years earlier and tree age can influence performance (McGranahan and Forde, 1985).

Received for publication 17 Apr. 1989. This work was partially supported by the Walnut Marketing Board. We thank Ben Iwakiri for data collection 1976-84. The cost of publishing this paper was defrayed in part by the payment of page charges. Under postal regulations, this paper therefore must be hereby marked advertisement solely to indicate this fact.
'Cisco' is a late-leafing and late-maturing cultivar, similar to 'Franquette' and other
French types. It leafs out $\approx 4$ weeks after 'Payne' and is ready for harvest 3 weeks after 'Payne'. It differs from most French types in that it bears fruit on lateral shoots. Lateral fruitfulness is often associated with high, early nut yields. However, yields of 'Cisco' in the selection block were consistently low for the first 10 years of evaluation. Yield improved substantially in the 11th year (1983) and has been fair to good since then. Lack of pollenizers may have accounted for the initially low yields in this protandrous cultivar, which itself requires a pollenizer for maximum yield.
Table 1. Comparison of 'Cisco' and 'Scharsch Franquette', 1976-85.

\begin{tabular}{|c|c|c|c|c|}
\hline \multirow[b]{2}{*}{ Trait $^{2}$} & \multicolumn{2}{|c|}{ Cisco } & \multicolumn{2}{|c|}{ Scharsch Franquette } \\
\hline & Mean & Range & Mean & Range \\
\hline $\begin{array}{l}\text { Leafing date } \\
\text { Peak fertility } \\
\text { First pollen shed } \\
\text { Last pollen shed } \\
\text { Harvest }\end{array}$ & $\begin{array}{l}16 \mathrm{Apr} . \\
5 \mathrm{May} \\
19 \mathrm{Apr} . \\
9 \text { May } \\
10 \text { Oct. }\end{array}$ & $\begin{array}{l}\text { 5-24 Apr. } \\
24 \text { Apr.-11 May } \\
\text { 8-30 Apr. } \\
29 \text { Apr.-24 May } \\
\text { 26 Sept.-20 Oct. }\end{array}$ & $\begin{array}{l}14 \text { Apr. } \\
2 \text { May } \\
13 \text { Apr. } \\
12 \text { May } \\
9 \text { Oct. }\end{array}$ & $\begin{array}{l}\text { 6-26 Apr. } \\
22 \text { Apr.-12 May } \\
\text { 6-26 Apr. } \\
\text { 26 Apr.-24 May } \\
\text { 5-20 Oct. }\end{array}$ \\
\hline $\begin{array}{l}\text { Lateral fruitfulness } \\
\text { Yicld (0-5 scale) }\end{array}$ & $\begin{array}{l}77 \% \\
2.2\end{array}$ & $\begin{array}{l}65 \% \text { to } 90 \% \\
1.0-4.5\end{array}$ & $\begin{array}{l}0 \% \\
2.4\end{array}$ & $\begin{array}{l}0 \% \\
2.0-3.0\end{array}$ \\
\hline $\begin{array}{l}\text { In-shell weight }(\mathrm{g}) \\
\text { Kernel weight }(\mathrm{g}) \\
\text { Kernel percent }\end{array}$ & $\begin{array}{l}13.5 \\
6.4 \\
47.0\end{array}$ & $\begin{array}{l}11.8-15.1 \\
5.2-7.8 \\
44.0-51.6\end{array}$ & $\begin{array}{l}11.3 \\
5.2 \\
46.0\end{array}$ & $\begin{array}{l}9.2-12.6 \\
4.2-6.0 \\
42.7-49.8\end{array}$ \\
\hline $\begin{array}{l}\text { Light color kernels } \\
\text { Shriveled kernels } \\
\text { Blanks } \\
\text { Dark veins } \\
\text { Dark spots }\end{array}$ & $\begin{array}{l}76 \% \\
1 \% \\
5 \% \\
2 \% \\
10 \%\end{array}$ & $\begin{array}{l}30 \% \text { to } 100 \% \\
0 \% \text { to } 10 \% \\
0 \% \text { to } 20 \% \\
0 \% \text { to } 20 \% \\
0 \% \text { to } 50 \%\end{array}$ & $\begin{array}{l}74 \% \\
4 \% \\
4 \% \\
8 \% \\
9 \%\end{array}$ & $\begin{array}{l}50 \% \text { to } 100 \% \\
0 \% \text { to } 10 \% \\
0 \% \text { to } 30 \% \\
0 \% \text { to } 70 \% \\
0 \% \text { to } 50 \%\end{array}$ \\
\hline $\begin{array}{l}\text { Shell texture } \\
\text { Shell color } \\
\text { Shell thickness } \\
\text { Shell seal }\end{array}$ & \multicolumn{2}{|c|}{$\begin{array}{l}\text { Medium } \\
\text { Medium-light } \\
\text { Medium } \\
\text { Well-sealed } \\
\end{array}$} & \multicolumn{2}{|c|}{$\begin{array}{l}\text { Medium } \\
\text { Medium } \\
\text { Medium } \\
\text { Well-sealed } \\
\end{array}$} \\
\hline
\end{tabular}

seal

${ }^{\mathrm{z}}$ Based on a four-tree or 10-nut sample each year.

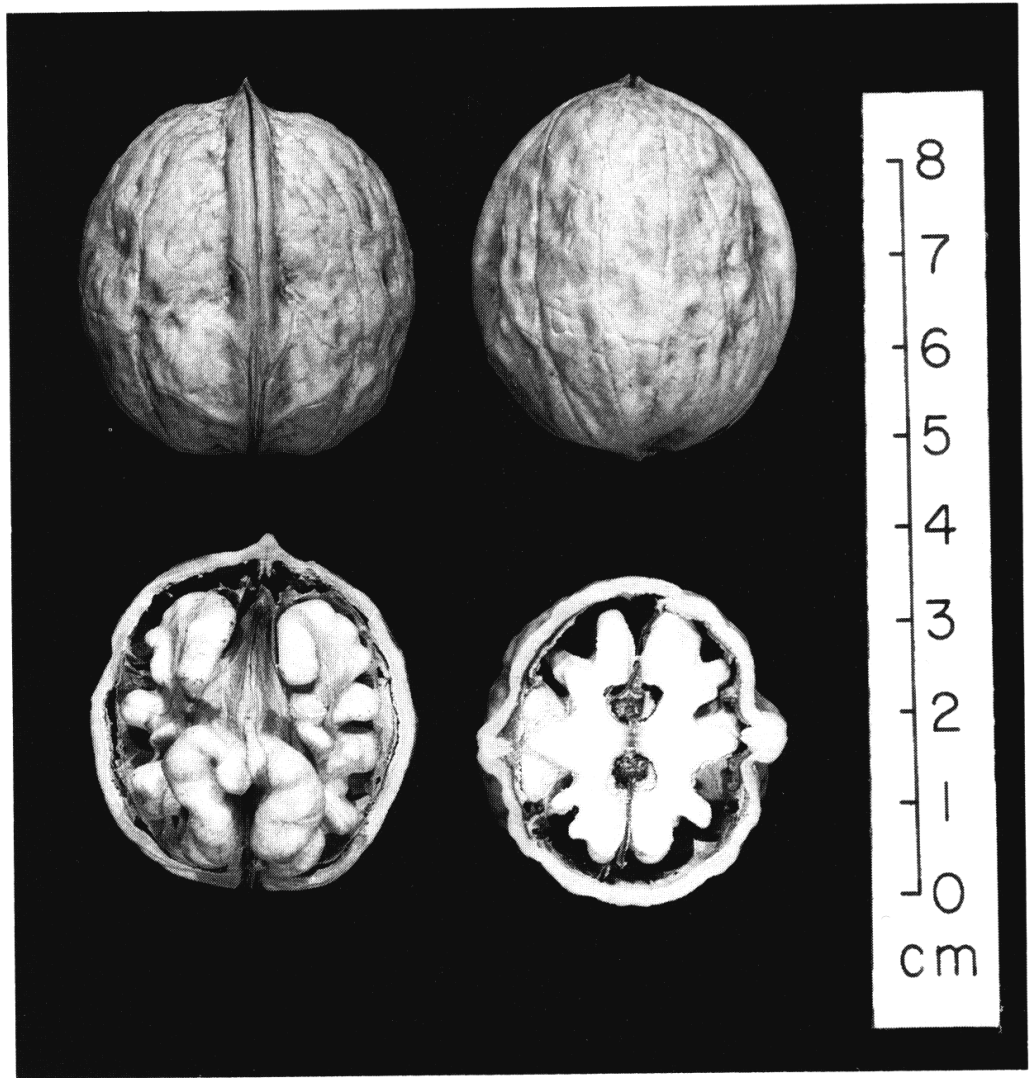

Fig. 1. 'Cisco' Persian walnut cultivar. 
POLLEN SHEDDING DURATION OF 'CISCO' AND 'FRANQUETTE' IN RELATION TO 'CHANDLER'

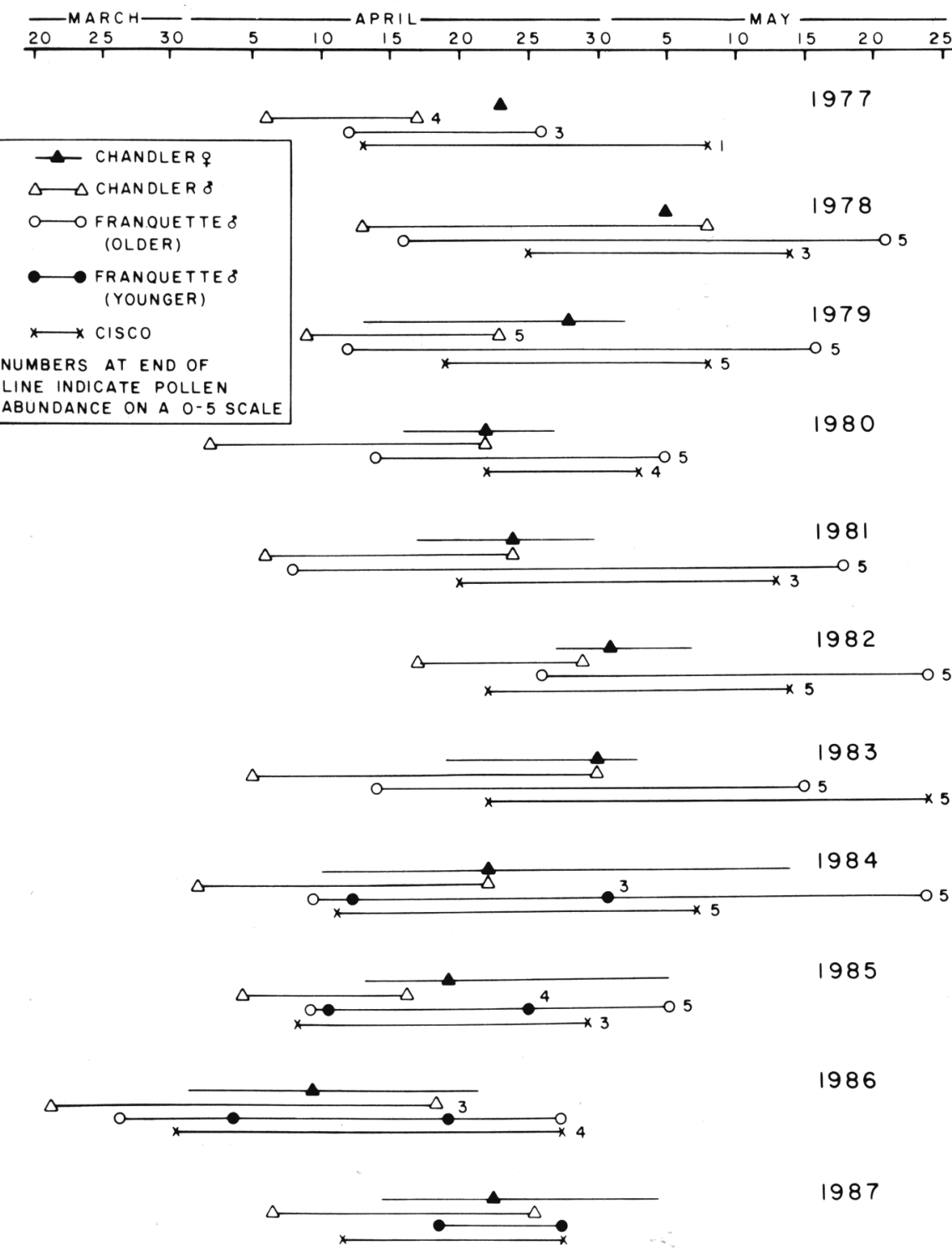

Fig. 2. Pollen-shedding duration of 'Cisco' and 'Franquette' in relation to 'Chandler'.

The shell (Fig. 1) is medium to light in color with a medium texture similar to 'Franquette'. In California, the shell is hard and well sealed, but, in cooler climates, may have poor shell formation (E. Germain, personal communication). The nut and kernel are slightly larger than 'Franquette'. Kernel color is variable, suggesting a sensitivity to environmental conditions. 'Cisco' is probably susceptible to blight, but escapes severe infection by leafing out after the spring rains have ceased in California. A low level of infection was recorded in 1980 and 1983; blight was recorded once for 'Franquette' during the same 10 years.

A 'Cisco' tree is semi-upright and intermediate in size, similar to 'Pedro'. It tends to send out long shoots with leaves concentrated at the ends. This trait may make it undesirable in a hedgerow planting configuration.

'Cisco' has several attributes that make it a satisfactory pollenizer for 'Chandler' and 'Howard'. It has shed a moderate to heavy pollen crop during the period of peak receptivity of both cultivars every year for 11 years. The overlap between the pistillate bloom of 'Chandler' and the pollen shedding period of 'Chandler', 'Franquette', and 'Cisco' is illustrated (Fig. 2). The 'Franquette' trees were in their 10th leaf and the 'Cisco' in their fifth leaf in 1977. Data on a younger set of 'Franquette' trees, grafted in 1980, is included for years 1984-87. The younger trees have a notably shorter period of pollen shedding.

Limited records are available on relative precocity of pollen-shedding of 'Cisco'. A low pollen yield was recorded in the selection block in the fourth leaf from grafting, moderate pollen yield in the sixth leaf, and a very high yield in the seventh leaf. It should be noted that these trees were grafted from a seedling that had not begun to shed pollen when propagated. In additional field trials, 'Cisco' has produced catkins in the second leaf from grafting, indicating that it can serve as a pollenizer at least 2 years earlier than 'Franquette.'

\section{Availability}

Small amounts of grafting or budwood are available through Foundation Seed and Plant Materials Service, Univ. of California, Davis, CA 95616.

\section{Literature Cited}

Forde, H.I. 1975. Walnuts, p. 439-455. In: J. Janick and J.N. Moore (eds.). Advances in fruit breeding. Purdue Univ. Press, West Lafayette, Ind.

McGranahan, G.H. and H.I. Forde. 1985. Relationship between clone age and selection trait expression in mature walnuts. J. Amer. Soc. Hort. Sci. 110:692-696.

Serr, E.F. and H.I. Forde. 1968. Ten new walnut varieties released. Calif. Agr. 22:8-10. 